\title{
KINERJA RANTAI PASOK BERAS DI KABUPATEN KARAWANG
}

\author{
PERFORMANCE OF RICE SUPPLY CHAINS IN KARAWANG DISTRICT
}

\author{
Ahmad Irfan Nurmahdy ${ }^{* 1}$, Machfud ${ }^{* * *}$, dan M. Faiz Syuaib $\left.{ }^{* * *}\right)$ \\ *) Sekolah Bisnis, IPB University \\ Jl. Padjajaran, Bogor, Indonesia 16151, Indonesia \\ ${ }^{* *}$ Departemen Teknologi Industri Pertanian, Fakultas Teknologi Pertanian, IPB University \\ Jl. Lingkar Kampus IPB Dramaga, Bogor 16680, Indonesia \\ ${ }^{* * *}$ Departemen Teknik Pertanian dan Biosistem, Fakultas Teknologi Pertanian, IPB University \\ Gedung Fateta, Kampus IPB Darmaga PO BOX 220, Bogor 16002, Indonesia
}

\begin{abstract}
Karawang Regency is an area of rice production center which will be a model for supply chain studies in this research. This study aims to determine the condition of the rice supply chain, determine the performance of the rice supply chain, and formulate efforts to improve the performance of the rice supply chain. The method used is the Food Supply Chain Network (FSCN) and Supply Chain Operation Network (SCOR) approaches. Based on the results of research members of the rice supply chain starts from farmers, traders, and rice mills. The value of performance metrics for farmers that are still not in line with expectations include the metric for orders delivered in full, perfect conditions, production costs, ranges of debt and receivables payments. Obtained several factors causing ineffective and inefficient performance of the rice supply chain in Karawang regency in each supply chain actor. Factors affecting farmers are the high cost of farming and the long range of payment of receivables can be overcome by increasing knowledge and application of technological developments and agricultural machinery, and strengthening the function of farmer groups. Factors affecting collecting traders are the low value of suitability of procurement flexibility. Factors affecting the low performance of rice milling are procurement flexibility and shipping flexibility.
\end{abstract}

Keywords: effort to improve the performance, paddy, performance measurement, SCOR, supply chain

\begin{abstract}
Abstrak: Kabupaten Karawang merupakan daerah sentra produksi beras yang akan menjadi model untuk studi rantai pasok pada penelitian ini. Penelitian ini bertujuan untuk mengetahui kondisi rantai pasok beras, mengetahui kinerja rantai pasok beras, dan merumuskan upaya peningkatan minerja rantai pasok beras. Metode penelitian menggunakan pendekatan Food Supply Chain Network (FSCN) dan Supply Chain Operation Network (SCOR). Hasil penelitian menunjukkan anggota rantai pasok beras dimulai dari petani, pedagang pengumpul, dan penggilingan padi. Nilai metrik kinerja pada petani yang masih tidak sesuai dengan harapan diantaranya yaitu pada metrik pemesanan terkirim secara utuh, kondisi sempurna, biaya produksi, rentang pembayaran hutang dan piutang. Nilai kinerja pada pedagang pengumpul yang masih belum sesuai harapan diantaranya pada metrik tepat jumlah, waktu siklus pemenuhan pemesanan, fleksibilitas pengadaan, fleksibilitas pengiriman dan biaya kirim. Faktor yang mempengaruhi petani yaitu tingginya biaya usaha tani dan rentang pembayaran piutang yang lama dapat diatasi dengan meningkatkan pengetahuan dan penerapan perkembangan teknologi dan mesin pertanian, serta memperkuat fungsi kelompok tani. Faktor yang memengaruhi pedagang pengumpul yaitu rendahnya nilai kesesuaian fleksibilitas pengadaan. Faktor yang mempengaruhi rendahnya kinerja penggilingan padi yaitu fleksibilitas pengadaan dan fleksibilitas pengiriman.
\end{abstract}

Kata kunci: upaya peningkatan kinerja, padi, pengukuran kinerja, SCOR rantai pasok

\footnotetext{
${ }^{1}$ Corresponding author:

Email: irfanrock342@yahoo.co.id
} 


\section{PENDAHULUAN}

Produksi padi Indonesia pada tahun 2018 mencapai sebanyak 78.81 juta ton Gabah Kering Panen (GKP) atau mengalami peningkatan sebanyak 1.45 juta ton (1.88 persen) dibandingkan tahun 2017 (Kementerian Pertanian 2019). Tingkat keberhasilan petani dalam memproduksi gabah tidak diikuti dengan meningkatnya kesejahteraan petani dikarenakan tingginya biaya, termasuk biaya rantai pasok yang dikeluarkan oleh petani (Swastika dan Sumaryanto (2012); Wahyuni (2016)).

Sharma dan Rai (2013) dalam meneliti rantai pasok padi yang masih menggunakan sistem tradisional juga mengungkapkan apabila tidak diantisipasi dapat mengakibatkan inefisiensi dalam proses penyaluran produk atau jasa. Penataan ulang perlu dilakukan dikarenakan kurangnya standar proses komunikasi dalam manajemen persediaan, sehingga mengakibatkan kekurangan jumlah persediaan saat jumlah permintaan tinggi, dan lebihnya persediaan saat jumlah permintaan rendah. Ketidakpastian menjadi sumber kendala dalam mengelola suatu rantai pasok. Ketidakpastian menimbulkan rasa tidak percaya terhadap rencana yang sudah dibuat. Perusahaan membuat suatu pengamanan di sepanjang rantai pasok. Pengamanan ini meliputi persediaan, waktu, kapasitas produksi maupun transportasi (Pujawan 2005, Bubun et al. 2018). Berbagi informasi merupakan aktivitas taktis dan operasional dalam manajemen rantai pasok, sehingga mampu mebantu orientasi menjadi aksi yang nyata guna mencapai tujuan rantai pasok (Gerry, 2016).

Ketersediaan produk secara tepat tempat dan tepat waktu saat ini sangat dipertimbangkan oleh konsumen. SCM (Supply Chain Management) dianggap sebagai solusi terbaik untuk memperbaiki tingkat produktivitas setiap pelaku (Fassoula, 2008; Anwar, 2011; Akhmad, 2013). Manajemen rantai pasok yang baik dapat menciptakan hubungan yang saling menguntungkan antar pelaku yang terkait untuk jangka yang panjang (Fatahilah et al. 2010; Sariyun, 2011). Konsumen saat ini tidak lagi sekedar membeli beras sebagai komoditas saja melainkan mulai beralih ke arah beras sebagai produk dengan keunggulan tertentu dari segi mutu dan rasa (Mardianto et al. 2005). Rachman (2013) menyatakan, kinerja rantai pasok ditentukan oleh kemampuan dalam hal reliabilitas, responsivitas, dan fleksibilitas dalam memenuhi kebutuhan konsumen dengan biaya serendah-rendahnya. Dengan adanya pengukuran kinerja, maka pelaku rantai pasok dapat menentukan arah perbaikannya. Kabupaten Karawang merupakan daerah bisnis beras yang baik untuk dijadikan studi rantai pasok beras.Tujuan dari penelitian ini yaitu: mengetahui kondisi rantai pasok beras di Kabupaten Karawang, mengetahui kinerja rantai pasok beras dalam lingkup Kabupaten Karawang, dan merumuskan upaya peningkatan kinerja rantai pasok beras di Kabupaten Karawang. Pengukuran kinerja rantai pasok dibatasi pada pelaku rantai pasok beras di Kabupaten Karawang saja yaitu petani, pedagang pengumpul, dan penggilingan padi dengan skala kecil dan sedang.

\section{METODE PENELITIAN}

Penelitian ini dilakukan di Kabupaten Karawang Provinsi Jawa Barat. Waktu pengumpulan data dimulai pada bulan Januari hingga Maret 2019. Pertimbangan pemilihan lokasi penelitian dan penentuan responden penggilingan padi dilakukan secara sengaja (purposive). Pemilihan responden pedagang pengumpul dan petani untuk menganalisis kondisi rantai pasok beras dilakukan dengan teknik snowball sampling dengan menelusuri saluran rantai pasok beras di lokasi penelitian berdasarkan informasi yang diperoleh dari anggota rantai pasok sebelumnya. Responden yang dipilih merupakan penggilingan padi kecil dan sedang di Kecamatan Lemahabang, Telagasari, dan Jatisari dimana daerah-daerah tersebut merupakan daerah yang memiliki jumlah penggilingan padi yang cukup banyak. Setiap Kecamatan diambil sebanyak dua penggilingan padi, empat orang pedagang pengumpul, dan enam orang petani, dengan total responden sebanyak 36 sampel, sehingga dapat menggambarkan kondisi rantai pasok beras di Kabupaten Karawang. Penentuan kriteria penggilingan padi berdasarkan input produksi. Penggilingan padi kecil memiliki kapasitas kurang dari satu ton gabah per jam, penggilingan sedang memiliki kapasitas satu sampai tiga ton gabah per jam, dan penggilingan padi besar memiliki kapasitas lebih dari tiga ton gabah per jam. Hipotesis dari penelitian ini yaitu ditemukannya masalah terhadap rantai pasok beras yang sudah terjadi di Kabupaten Karawang. kerangka penelitian ini dapat dilihat pada Gambar 1.

Teknik pengolahan data dan metode analisis data pada penelitian ini melalui tahapan Analisis deskriptif untuk menggambarkan kondisi rantai pasok beras menggunakan kerangka Food Supply Chain Network (FSCN). Penerapan model Supply Chain Operation 
Network (SCOR) dapat mengidentifikasi indikator kinerja rantai pasok dengan menunjukkan proses rantai pasok perusahaan, sehingga dapat dijadikan evaluasi dalam meningkatkan kinerja (Wayyum et al. (2010); Kurien dan Qureshi (2012); Ambe (2014)). Pengukuran kinerja rantai pasok beras dengan berdasarkan langkah dengan tahap: penentuan metrik kinerja dengan menggunakan metode SCOR, pembobotan menggunakan pairwise comparison, perhitungan kinerja. Perumusan upaya peningkatan kinerja rantai pasok dengan langkah: analisis kesenjangan (gap analysis), analisis masalah rantai pasok (diagram tulang ikan), dan menyusun upaya peningkatan kinerja.

\section{HASIL}

\section{Kondisi Rantai Pasok Beras}

Petani

Petani merupakan anggota rantai yang berperan sebagai penyedia utama bahan baku berupa gabah. Menurut hasil dari wawancara, para petani menjual semua hasil panenannya kepada pedagang pengumpul. Petani merasa sangat terbantu dengan adanya pedagang pengumpul.
Pedagang pengumpul

Pedagang pengumpul merupakan pedagang yang membeli gabah dari petani dan menyalurkannya kepada pabrik penggilingan padi. Pedagang pengumpul terbagi menjadi dua kriteria yaitu pedagang pengumpul kecil dan pedagang pengumpul besar, dibedakan berdasarkan jumlah kapasitas dalam menampung gabah dan mencari atau memberi informasi mengenai gabah. Pedagang pengumpul kecil berperan sebagai orang yang mencari informasi dan mengontrol kualitas gabah, sedangkan pedagang pengumpul besar setelah memperoleh informasi mengenai kualitas gabah dilapangan, mereka akan memberikan informasi tersebut kepada pabrik penggilingan padi.

\section{Penggilingan padi}

Penggilingan padi merupakan anggota rantai yang berperan menampung dan membeli GKP dari pedagang pengumpul untuk dilakukan pengolahan hingga menjadi beras putih. Kegiatan pembelian GKP (Gabah Kering Panen) dari pedagang pengumpul dilakukan di lokasi penggilingan padi. Beras yang sudah dikemas disimpan di gudang penyimpanan atau langsung dimuat ke dalam truk untuk langsung diantarkan ke pedagang grosir di Pasar Johar, Kabupaten Karawang.

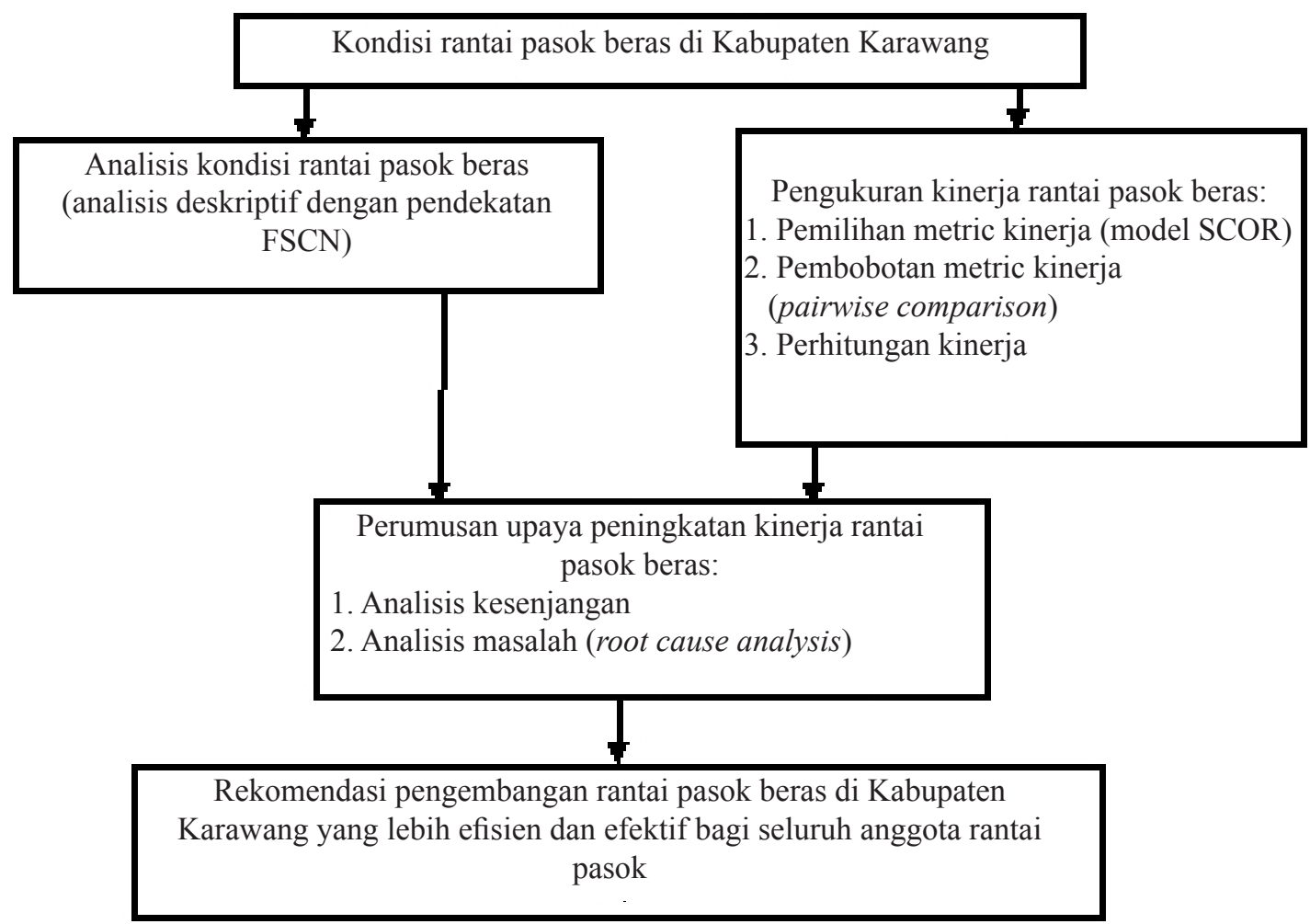

Gambar 1. Kerangka pemikiran penelitian 


\section{Manajemen Rantai Pasok}

Pemilihan mitra

Pedagang pengumpul memiliki rasa keterikatan secara sosial dengan petani dalam membeli gabah karena telah bekerja sama dalam waktu yang cukup lama. Petani akan merasa tidaknyaman jika menolak pedagang pengumpul yang membeli gabahnya. Harga yang ditawarkan pedagang pengumpul dianggap menjadi harga yang umum. Proses jual beli gabah dari petani diperlukan rasa kepercayaan pada setiap anggota rantainya, karena calo yang mencari gabah tersebut berasal dari daerah yang sama dengan para petaninya. Anggota rantai berikutnya, yaitu penggilingan padi dimana dalam memilih pemasok sangat mempertimbangkan kualitas dan kuantitas dari pedagang pengumpul.

\section{Kesepakatan kontraktual}

Kesepakatan yang terjadi pada setiap anggota rantai pasok padi di Kabupaten Karawang tidak dilakukan melalui kontrak secara formal atau tertulis, namun hanya melalui kesepakatan secara lisan. Kesepakatan yang dibuat antar kedua belah pihak baik dari petani padi ke pedagang pengumpul, maupun pedagang pengumpul ke penggilingan padi yaitu mengenai kuantitas penjualan dan kualitas gabah maupun beras kepada calon pembeli.

\section{Sistem transaksi}

Sistem penjualan yang terjadi secara umum di tingkat petani yaitu dilakukan dengan sistem kiloan/timbangan. Sistem transaksi yang terjadi diantara anggota rantai pasok beras umumnya dilakukan dengan mekanisme tawar menawar. Sistem pembayaran yang dilakukan oleh penggilingan padi kepada pedagang pengumpul maupun pedagang pengumpul kepada petani menggunakan sistem pembayaran sebagian terlebih dahulu, dimana uang muka tersebut digunakan sebagai modal dari pedagang pengumpul dalam mencari GKP.

\section{Sumber Daya}

Sumber daya fisik

Sumber daya fisik yang dimiliki oleh petani berupa lahan sawah, saprotan, dan sumber daya penunjang lainnya. Pedagang pengumpul memiliki beberapa sumber daya fisik berupa timbangan, karung, tali rafia, handphone dan sepeda motor. Penggilingan padi memiliki sumber daya fisik berupa mesin penggilingan yang terdiri dari mesin molen dan mesin polisher serta lapangan jemur dan mesin oven.

\section{Sumber daya teknologi}

Teknologi yang biasa diterapkan petani padi yaitu sebatas teknologi budidaya, seperti penggunaan benih dengan varietas unggul, penggunaan hand sprayer, penggunaan mesin traktor, dan menggunakan mesin perontok. Penggilingan padi menerapkan teknologi dalam melakukan kegiatan produksi yaitu dengan menggunakan mesin penggilingan yang terdiri dari 4 tahap. Penggilingan padi di Kabupaten Karawang juga memiliki mobil truk dengan kapasitas 10 ton per satu kali pengangkutan. Mobil truk tersebut digunakan untuk mengirim beras ke pedagang grosir di Pasar Johar, Kabupaten Karawang dan juga disewakan kepada pedagang pengumpul padi.

\section{Sumber daya manusia}

Dalam kegiatan penanaman dan panen, petani mempekerjakan 10-20 orang tenaga kerja. Tenaga kerja yang dibutuhkan oleh pedagang pengumpul sekitar 10 orang. Penggilingan padi membutuhkan tenaga kerja untuk kegiatan penjemuran, penggilingan, sortasi, dan pengemasan berkisar 2-6 orang.

Sumber daya modal

Sebagian besar petani di Kabupaten Karawang menggunakan modal untuk melakukan usaha budidaya padi yang berasal dari pinjaman bank dan sistem bagi hasil dengan pemilik lahan. Modal yang digunakan oleh pedagang pengumpul berasal dari uang muka yang diperoleh dari penggilingan padi. Penggilingan padi di Kabupaten Karawang lebih sering menggunakan modal pribadi untuk melakukan kegiatan produksinya.

\section{Hubungan Proses Bisnis Rantai Pasok}

Pedagang pengumpul, dan penggilingan padi dalam kasus ini melakukan siklus procurement, sedangkan penggilingan padi melakukan siklus manufacturing. Kemudian siklus replenishment dilakukan oleh pedagang pengecer. Perbedaan dari siklus-siklus, yaitu jumlah pesanan yang dilakukan. Apabila semakin mendekati siklus procurement maka jumlah pesanan akan semakin banyak. 
Dalam kasus ini terjadi permintaan konsumen akhiryang menggerakkan pedagang pengecer dalam merespon permintaan konsumen, merupakan proses pull. Siklus replenishment, manufacturing, dan procurement terjadi saat sebelum pemesanan oleh konsumen akhir dan pedagang pengecer sehingga penggilingan padi, pedagang pengumpul, dan petani dalam kasus ini melakukan proses push.

\section{Pola distribusi}

\section{Aliran produk}

Dalam rantai pasok ini produk yang dialirkan bermula dari bahan baku yang berupa GKP hingga menjadi produk akhir yang berupa beras. Dalam hal ini petani menjadi pihak yang paling awal untuk mengalirkan produk. Aliran produk rantai pasok beras di Kabupaten Karawang dapat dilihat pada Gambar 2.

\section{Aliran finansial}

Aliran finansial dalam rantai pasok beras di Kabupaten Karawang yaitu berupa uang pembayaran atas produk yang dijual kepada anggota rantai yang menjadi mitra. Uang yang dibayarkan akan digunakan kembali sebagi modal untuk melakukan produksi, dengan demikian terbentuklah siklus. Aliran finansial dimulai dari pedagang pengecer hingga petani. Aliran finansial rantai pasok beras di Kabupaten Karawang pada Gambar 3.
Aliran informasi

Aliran informasi pada rantai pasok beras di Kabupaten Karawang berlangsung secara timbal-balik yang dimulai dari petani hingga ke penggilingan padi. Informasi yang dialirkan antar anggota rantai pasok dapat berupa informasi harga, kualitas produk, dan kuantitas produk. Aliran informasi rantai pasok beras di Kabupaten Karawang dapat dilihat pada Gambar 4.

\section{Anggota rantai pendukung}

Petani padi membutuhkan bahan baku input seperti benih padi, pupuk, dan obat-obatan. Input tersebut diperoleh petani dari toko sarana pertanian. Petani dalam melakukan kegiatan pengolahan lahan tidak memiliki alat seperti traktor dikarenakan keterbatasan modal, namun ada pihak yang menyewakan mesin traktor dan mesin perontok berikut jasanya. Pedagang pengumpul membutuhkan bahan baku pengemasan berupa karung GKP ukuran $60 \mathrm{Kg}$, tali rafia, serokan gabah, timbangan, dan serokan gabah yang mampu diperoleh dari toko khusus penjual karung dan took kelontong di lingkungan desa. Penggilingan padi juga memperooleh karung dari toko khusus penjual karung, serta memperoleh bahan bakar dari pom bensin terdekat.

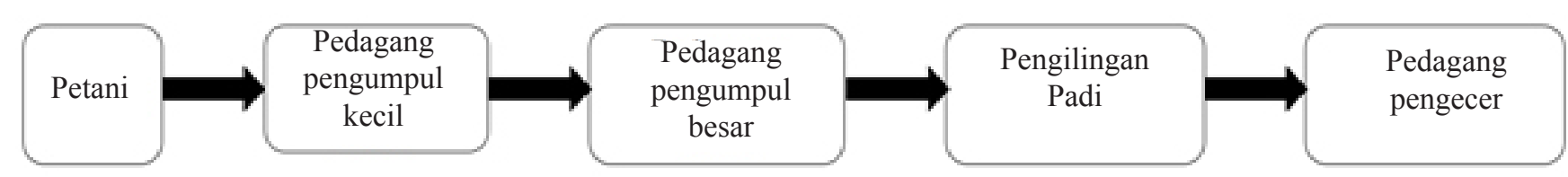

Gambar 2. Aliran produk rantai pasok beras di Kabupaten Karawang

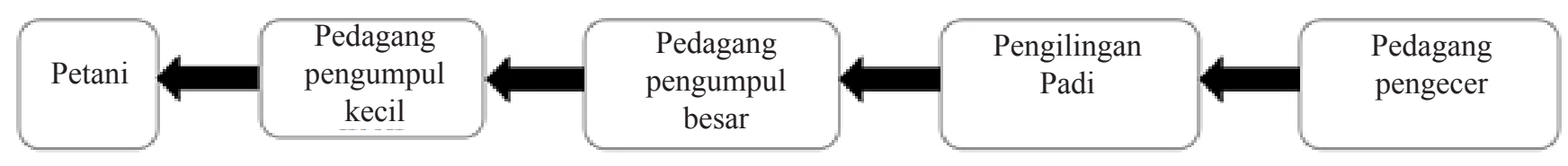

Gambar 3. Aliran finansial rantai pasok beras di Kabupaten Karawang

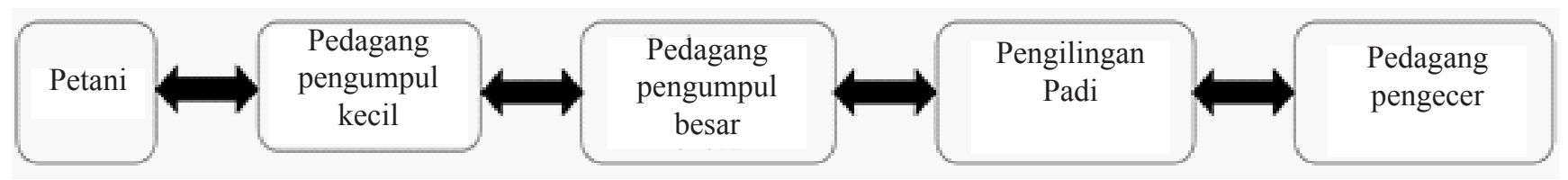

Gambar 4. Aliran informasi rantai pasok beras di Kabupaten Karawang 
Jaminan identitas merek

Beras yang berasal dari rantai pasok di Karawang memiliki merek yang berbeda-beda. Penggilingan padi pada umumnya mencantumkan masing-masing sesusai nama penggilingan. Penggunaan merk produk hanya diterapkan oleh penggilingan padi saja. Petani dan pedagang pengumpul tidak mencantumkan merk pada produknya, sehingga produk dari petani dan pedagang pengumpul tidak dapat terlacak melainkan hanya produk beras dari penggilingan padi saja.

Aspek risiko

Dalam melakukan kegiatan budidaya, petani menghadapi risiko berupa kegagalan panen dan rendahnya kualitas maupun kuantitas gabah. Pedagang pengumpul memiliki risiko berupa harga jual yang rendah. Risiko yang dihadapi oleh penggilingan padi di Kabupaten Karawang, yaitu rendemen yang dihasilkan tidak sesuai yang diharapkan.

\section{Proses membangun kepercayaan}

Proses membangun kepercayaan diantara anggota rantai pasok beras di Kabupaten Karawang terjadi dikarenakan hubungan kerjasama yang terjalin sudah berjalan cukup lama. Kerja sama yang terjalin sepanjang rantai pasok beras di Kabupaten Karawang tidak terikat dalam kontrak secara formal, namun hanya mengandalkan kontrak secara informal melalui lisan. Rasa kepercayaan antar anggota rantai mulai dari petani hingga penggilingan padi tetap bisa terjalin karena masing-masing menjaga hubungan yang baik.

\section{Perhitungan Kinerja Rantai Pasok Beras}

Petani

Dalam semusim petani mampu menghasilkan gabah sebanyak $5.755 \mathrm{Kg} / \mathrm{Ha}$. Harga gabah yang dihasilkan petani pada saat panen memiliki harga tawar sebesar $\mathrm{Rp} 5.000 / \mathrm{Kg}$ GKP. Total waktu yang dibutuhkan petani dalam menyediakan gabah, yaitu 163 hari. Total biaya yang dikeluarkan petani dalam semusim untuk membudidayakan padi sebesar Rp26.070.000. Diperoleh hasil nilai total kinerja petani dalam rantai pasok beras di Kabupaten Karawang sebesar 79,18.

\section{Pedagang pengumpul}

Dalam metrik pemenuhan pesanan sempurna pedagang pengumpul dapat mengumpulkan gabah sebanyak 12 $139 \mathrm{Kg}$. Waktu siklus pemenuhan pesanan pedagang pengumpul membutuhkan waktu selama dua hari. Siklus produksi yang dibutuhkan pedagang pengumpul yaitu selama satu hari. Sedangkan waktu siklus pengiriman pedagang pengumpul membutuhkan waktu selama satu hari. Diperoleh hasil nilai total kinerja pedagang pengumpul dalam rantai pasok beras di Kabupaten Karawang sebesar 73,98.

\section{Penggilingan padi}

Dalam melakukan kegiatan pengolahan gabah menjadi beras, penggilingan padi membutuhkan biaya sebesar Rp5.654. Harga beras yang dihasilkan oleh penggilingan padi di Kabupaten Karawang sebesar $\mathrm{Rp} 10.500 / \mathrm{Kg}$ beras, dengan rendemen padi menjadi beras mencapai $55 \%$. Siklus waktu produksi terdiri dari beberapa kegiatan yaitu: waktu penjemuran selama 8 jam, waktu penggilingan selama 9 jam, dan waktu pengemasan selama 9 jam. Diperoleh hasil nilai total kinerja penggilingan padi dalam rantai pasok beras di Kabupaten Karawang sebesar 70,80.

\section{Perumusan Upaya Peningkatan Kinerja Rantai Pasok Beras}

\section{Analisis kesenjangan}

Petani memiliki nilai tingkat keseuaian yang dibawah target pada metrik biaya, terutama dalam biaya tenaga kerja budi daya sebesar 61 persen dan tenaga kerja panen dan pascapanen sebesar 61,54 persen. Petani tidak melakukan seluruh kegiatan sendiri, tetapi membutuhkan banyak tenaga kerja. Sebagai contoh saat panen raya terkadang jumlah tenaga panen cukup sedikit atau berebut dengan petani lainnya, sehingga menyebabkan meningkatnya biaya tenaga kerja. Metrik rentang pembayaran piutang juga merupakan metrik yang memiliki nilai kinerja yang dibawah target, yaitu sebesar 34,92 persen, hal tersebut dikarenakan pedagang pengumpul terkadang masih harus memutarkan modalnya terlebih dahulu. Faktor kualitas gabah juga dapat memengaruhi lamanya pembayaran gabah petani. 
Metrik tepat jumlah pada pedagang pengumpul memiliki nilai keseuaian diabawah target yaitu sebesar 52 persen, hal tersebut dipengaruhi oleh permintaan dari konsumen yang semakin meningkat dan pedagang pengumpul di Kabupaten Karawang terpaksa harus mencari bahan baku gabah keluar daerah Kabupaten Karawang. Metrik tersebut memengaruhi nilai kesesuaian metrik lainnya seperti waktu penerimaan bahan baku yaitu sebesar 50 persen. Rendahnya nilai kesesuaian pada metrik tepat jumlah juga memberikan pengaruh kepada rendahnya nilai keseuaian metrik fleksibilitas pengadaan yaitu sebesar 36,11 persen.

Penggilingan padi memiliki nilai tingkat keseuaian yang dibawah target pada metrik ketepatan jumlah, yaitu sebesar 32,82 persen, hal tersebut dikarenakan permintaan konsumen yang semakin meningkat menuntut penggilingan padi harus memproduksi beras lebih. Rendahnya milai kesesuaian metrik tersebut memberikan pengaruh kepada metrik lain seperti waktu penerimaan bahan baku dan fleksibilitas pengadaan secara berturut-turut sebesar 50 dan 33,5 persen. Penggunaan mesin pengolahan padi yang masih tergolong belum modern akan memberikan pengaruh terhadap metrik fleksibilitas pengiriman sebesar 35,55 persen. Sederhananya teknologi yang digunakan juga memberikan pengaruh terhadap metrik biaya penjemuran sebesar 42,39 persen, biaya penggilingan sebesar 37,82 persen, biaya pengemasan 30,32 persen, dan biaya pengiriman sebesar 63,16 persen.

\section{Analisis masalah}

Berdasarkan pengukuran kinerja dan analisis kesenjangan pada petani, diketahui bahwa metrik kinerja yang memiliki nilai kesesuaian tidak sesuai harapan yaitu tingginya biaya usaha tani. Tingginya biaya usaha tani disebabkan oleh beberapa faktor diantaranya teknologi yang digunakan oleh petani padi di Kabupaten Karawang masih tergolong sederhana, hal demikian dikarenakan petani padi di Kabupaten Karawang masih belum merasa terbuka terhadap perkembangan penggunaan mesin teknologi pertanian. Jumlah tenaga kerja juga merupakan faktor yang memengaruhi tingginya biaya usaha tani. Masa tanam dan panen merupakan masa-masa yang cukup krusial dalam melakukan kegiatan usahatani, pada kondisi tersebut juga jumlah tenaga kerja yang dibutuhkan oleh petani cukup banyak. Jumlah tenaga kerja untuk bidang pertanian di Kabupaten Karawang terbilang terbatas dikarenakan faktor usia dan persaingan dengan bidang pekerjaan lainnya seperti bidang industri.

Rentang pembayaran piutang juga merupakan metrik yang memiliki nilai kesenjangan yang tidak sesuai harapan, hal tersebut dipengaruhi oleh beberapa faktor, yaitu keterbatasan modal dari pedagang pengumpul dan jumlah gabah yang dibutuhkan oleh pedagang pengumpul untuk memenuhi permintaan cukup banyak. Pedagang pengumpul menggunakan seluruh modal usahanya berasal dari pihak penggilingan padi dan jumlah pesanan gabah cukup banyak, maka pedagang pengumpul harus mencari gabah keluar Kabupaten Karawang. Modal yang diterima oleh pedagang pengumpul akan terlebih dahulu dibayarkan kepada petani yang berada di luar Kabupaten Karawang.

Berdasarkan pengukuran kinerja dan analisis kesenjangan pada pedagang pengumpul, diketahui bahwa metrik kinerja yang memiliki nilai kesesuaian tidak sesuai harapan, yaitu rendahnya fleksibilitas pengadaan. Nilai keseuaian metrik fleksibilitas yang rendah dikarenakan beberapa faktor yaitu kurangnya memperoleh bahan baku gabah dan waktu untuk memperoleh bahan baku yang lama. Permintaan gabah yang cukup tinggi dari pihak penggilingan padi menuntut pedagang pengumpul mencari gabah hingga keluar Kabupaten Karawang, dengan kata lain hasil panen dari petani di Kabupaten Karawang masih belum mencukupi permintaan dari konsumen. Pedagang pengumpul dalam mencari gabah keluar Kabupaten Karawang juga akan memakan waktu hingga dua kali lipat lebih lama sehingga waktu yang dibutuhkan oleh pedagang pengumpul dalam mencari bahan baku juga memiliki nilai keseuaian yang rendah.

Berdasarkan pengukuran kinerja dan analisis kesenjangan pada penggilingan padi sama halnya dengan pedagang pengumpul, diketahui bahwa metrik kinerja yang memiliki nilai kesesuaian tidak sesuai harapan yaitu rendahnya fleksibilitas pengadaan. Nilai kesesuaian metrik fleksibilitas yang rendah dikarenakan beberapa faktor, yaitu kurangnya memperoleh bahan baku gabah dan waktu untuk memperoleh bahan baku yang lama. Permintaan gabah yang cukup tinggi dari konsumen menuntut penggilingan padi meminta gabah dengan kuantitas yang lebih besar, dengan kata lain hasil panen dari petani di Kabupaten Karawang masih belum mencukupi permintaan dari konsumen. Pedagang pengumpul dalam mencari gabah keluar Kabupaten 
Karawang juga akan memakan waktu hingga dua kali lipat lebih lama, sehingga waktu yang dibutuhkan oleh pedagang pengumpul dalam mencari bahan baku juga memiliki nilai keseuaian yang rendah.

Faktor yang memiliki nilai keseuaian yang tidak sesuai harapan lainnya yaitu fleksibilitas pengiriman. Rendahnya fleksibilitas pengiriman dipengaruhi oleh beberapa faktor yaitu tingginya biaya pengolahan gabah dan tingginya biaya pengiriman. Penggilingan padi dalam mengolah gabah masih menggunakan teknologi yang terbilang sederhana, seperti dalam menjemur gabah penggilingan padi masih menggunakan lapangan jemur dan panas matahari saja. Mesin penggilingan yang digunakan juga hanya mesin penggilingan yang terdiri dari 4 tahap, yaitu tahap pertama yaitu proses pecah kulit menggunakan mesin molen yang terdiri dari dua buah mesin dan masih membutuhkan cukup banyak tenaga kerja manusia. Gabah yang sudah selesai diolah menjadi beras putih kemudian langsung dikemas menggunakan kemasan karung plastik ukuran $50 \mathrm{Kg}$. kegiatan pengemasan masih banyak menggunakan tenaga manusia.

\section{Implikasi Manajerial}

\section{Petani}

Tingginya biaya usaha tani yang dikeluarkan oleh petani yang disebabkan oleh beberapa faktor seperti biaya input, alsintan, dan tenaga kerja yang tinggi. Faktor tersebut dapat diatasi dengan cara penggunaan alat mesin yang lebih modern. Sebagai contoh dalam melakukan kegiatan budidaya padi Suhendra (2013) menjelaskan pada kondisi petakan sawah yang luas dengan kedalaman lumpur kurang dari $40 \mathrm{~cm}$, penggunaan mesin transplanter dapat membantu memecahkan permasalahan tenaga kerja saat tanam. Tommy et al. (2008) mengungkapkan, dengan menggunakan mini combine harvester tingkat kehilangan pada proses pemanenan bias ditekan hingga mencapai kurang dari 2 persen dan tingkat kebersihan gabah mencapai lebih dari 95 persen, hal ini sejalan dengan penelitian Amerina (2014) dimana petani tidak ditunjang dengan pengetahuan yang baik.

Rentang pembayaran piutang kepada petani terbilang lama, hal tersebut dikarenakan kecenderungan terhadap satu pedagang pengumpul saja dan mutu gabah yang dihasilkan masih kurang maksimal. Faktor tersebut dapat diatasi dengan hasil penelitian Sobichin (2013) yaitu, petani harus mengoptimalkan peran kelompok tani dalam kegiatan panen dan pascapanen hasil panen padi secara terpadu dan terkoordinir. Bersatunya petani akan meningkatkan nilai tawar atau beragaining power terhadap pelaku tata niaga gabah dan beras. Optimalnya hasil panen petani akan mempermudah pedagang pengumpul dalam mencari gabah, sehingga rentang pembayaran piutang akan tidak terlalu lama. Bambang (2017) menyatakan, model budidaya padi dengan penerapan komponen epidemik secara selektif harus dirancang terlebih dahulu dengan penggunaan benih yang bersertifikat, pengolahan tanah secara sempurna dan pemberian bahan organik. Pembatasan penggunaan pestisida kimia pun harus didasarkan pada ambang kerusakan atau ambang kendali agar biaya aplikasi pestisida dapat diminimalisir.

\section{Pedagang pengumpul}

Nilai kinerja fleksibilitas pengadaan yang rendah disebabkan oleh keterbatasan modal yang dimiliki oleh pedagang pengumpul. Endang (2012) menyatakan, modal usaha yang dilakukan secara individu dan bersama berpengaruh signifikan terhadap pengembangan usaha, sedangkan strategi pemasaran secara individu tidak memberikan pengaruh signifikan terhadap pengembangan usaha, namun yang dilakukan secara bersama akan memberikan pengaruh yang signifikan.

\section{Peggilingan padi}

Meningkatnya kebutuhan dan permintaan beras dari konsumen memaksa penggilingan padi memproduksi beras dengan jumlah yang lebih banyak. Hasil penilaian nilai kesesuaian fleksibilitas pengdaan dan pengiriman pada penggilingan padi masih belum sesuai harapan. Faktor yang menyebabkan tidak sesuainya nilai sesuai harapan dipengaruhi juga oleh beberapa faktor yang sudah dibahas sebelumnya. Rendahnya nilai kesesuaian fleksibilitas pengiriman dipengaruhi oleh tingginya biaya dalam mengolah gabah. Penggilingan padi kecil dan sedang di Kabupaten Karawang masih menggunakan mesin pengolahan gabah yang sederhana dan sudah berumur. Firdaus (2019) mengungkapkan, umur mesin penggilingan sudah tua dan teknologi mesin yang dimiliki sudah tertinggal dengan konfigurasi mesin sederhana. Kondisi tersebut menghasilkan rendemen, kualitas, dan efisiensi yang rendah berakibat 
pada tingginya biaya produksi. Peningkatan dan pembaharuan mesin diperlukan agar penggilingan dapat mempercepat kegiatan produksi demi memenuhi kebutuhan konsumennya.

\section{KESIMPULAN DAN SARAN}

\section{Kesimpulan}

Anggota rantai pasok beras dimulai dari petani, pedagang pengumpul, dan penggilingan padi. Pola saluran rantai tersebut sudah berjalan dalam waktu yang cukup lama. Petani merasa cukup terbantu dengan adanya pedagang pengumpul dalam menjual gabahnya. Pedagang pengumpul hanya menyalurkan gabah saja. Penggilingan padi melakukan seluruh kegiatan pengolahan hingga menjadi beras putih.

Pelaku rantai pasok beras di Kabupaten Karawang dari petani, pedagang pengumpul dan penggilingan padi memiliki beberapa metrik kinerja yang masih tidak sesuai dengan harapan. Nilai metrik kinerja pada petani yang masih tidak sesuai dengan harapan diantaranya yaitu pada metrik pemesanan terkirim secara utuh, kondisi sempurna, biaya produksi, rntang pembayaran hutang dan piutang. Nilai kinerja pada pedagang pengumpul yang masih belum sesuai harapan diantaranya pada metrik tepat jumlah, waktu siklus pemenuhan pemesanan, fleksibilitas pengadaan dan biaya kirim. Nilai kinerja yang masih belum sesuai harapan pada penggilingan padi yaitu pada metrik pemesanan terkirim secara utuh, waktu siklus pengadaan, fleksibilitas pengdaan dan pengiriman, biaya produksi, dan biaya pengiriman.

Diperoleh beberapa faktor penyebab kurang efektif dan efisiennya kinerja rantai pasok beras di Kabupaten Karawang pada setiap pelaku rantai pasok. Faktor yang memengaruhi petani, yaitu tingginya biaya usaha tani dan rentang pembayaran piutang yang lama dapat diatasi dengan meningkatkan pengetahuan dan penerapan perkembangan teknologi dan mesin pertanian, serta memperkuat fungsi kelompok tani. Perbaikan rentang pembayaran piutang pada petani juga akan mengatasi rendahnya nilai keseuaian pedagang pengumpul dan penggilingan padi pada faktor fleksibilitas pengadaan. Faktor yang memengaruhi pedagang pengumpul yaitu rendahnya nilai kesesuaian fleksibilitas pengadaan. Faktor yang memengaruhi rendahnya kinerja penggilingan padi yaitu fleksibilitas pengadaan dan fleksibilitas pengiriman. Peningkatan fleksibilitas pengiriman penggilingan padi dapat dilakukan dengan cara meningkatkan teknologi yang digunakan.

\section{Saran}

Perlu dilakukan penelitian lebih lanjut mengenai penelitian ini dengan cakupan ruang lingkup yang lebih luas hingga konsumen akhir. Upaya peningkatan kinerja rantai pasok beras di Kabupaten Karawang, diperlukan perbaikan atau peningkatan terhadap beberapa kinerja yang masih belum tercapai baik dari petani hingga ke penggilingan padi. Pewujudan perbaikan kinerja rantai pasok beras di Kabupaten Karawang, dibutuhkan komitmen yang tinggi dari setiap pelaku rantai pasok dengan cara menjalankan peran, tugas, dan kewajibannya secara fokus.

\section{DAFTAR PUSTAKA}

Akhmad M. 2013. Model dinamis supply chain beras berkelanjutan dalam upaya ketahanan pangan nasional. Jurnal Management dan Agribisnis 10(2): 81-89.

Ambe IM. 2014. Key indicators for optimising sc performance: the case of light vehicle manufacturers in South Africa. Journal of Applied Business Research 30(1): 277-290.

Anwar S N. 2011. Manajemen Rantai Pasokan (Supply Chain Management): Konsep dan Hakikat. Jurnal Dinamika Informatika 3(2): 92-98.

Bambang N. 2017. Pengendalian penyakit tanaman padi berwawasan lingkungan melalui pengelolaan komponen epidemik. Jurnal Litbang Pertanian 37(1): 1-12.

Bubun, Sukardi, Ono S. 2018. Kinerja Rantai Pasok Kedelai di Kabupaten Grobogan. Jurnal Aplikasi Bisnis dan Manajemen 4(1): 32-43.

Endang P. 2102. Pengaruh karakteristik wirausaha, modal usaha, strategi pemasaran terhadap perkembangan UMKM di Desa Dayaan dan Kalilondo Salatiga. Jurnal Among Makarti 5(9): 13-28.

Fatahilah YH, Marimin, Harianto. 2010. Analisis kinerja rantai pasok agribisnis sapi potong: studi kasus pada PT Kariyana Gita Utama, Jakarta. Jurnal Teknologi Industri Pertanian 20(3):193205.

Fassoula ED. 2008. Transforming the supply chain. Journal of Manufacturing Technology 
Management 17(5): 848-860.

Firdaus YR. 2019. Strategi Penguatan Usaha Penggilingan Padi Kecil di Kabupaten Indramayu [Tesis]. Bogor: Institut Pertanian Bogor.

Gerry G. 2016. Keterkaitan antara orientasi rantai pasok, berbagai manajemen informasi dan kepuasan inter-relasi antar perusahaan. Jurnal Manajemen dan Bisnis 12(1): 1-9.

Kementrian Pertanian. 2019. Data Lima Tahun Terakhir. https : // www . pertanian . go . id / home / ? show $=$ page $\&$ act $=$ view $\&$ id $=61$. [21 Jun 2019.

Kurien GP, Qureshi MN. 2012. Performance measurement system for green scs using modified balanced score card and analytical hierarchical process. Scientific Research and Essays 7(36): 3149-3161.

Mardianto S, Supriatna Y, Agustin NK. 2005. Dinamika pola pemasaran gabah dan beras di Indonesia. Forum Peneliti Agro Ekonomi 23(2): 116-131.

Pujawan, I Nyoman. 2005. Supply Chain Management. Surabaya: Guna Widya.

Rachman T. 2013. Pengukuran Kinerja SCM. Jakarta: Universitas Esa Unggul.

Sariyun. 2011. Manajemen rantai pasokan (Supply Chain Management): konsep dan hakikat. Jurnal Dinamika Informatika 3(2): 454-472.

Sharma RM GS, Rai SS. 2013. The effect of supply chain management of rice in india: rice processing company's perspective. International
Journal of Managing Value and Supply Chains 4(1): 25-36.

Sobichin M. 2013. Nilai rantai distribusi komoditas gabah dan beras di Kabupaten Batang. Jurnal Unnes 2(1): 1-8.

Suhendra T. 2013. Pengaruh Pengembangan Mesin Tanam Pindah Bibit (Rice Transplanter) dalam Rangka Mengarasi Kelangkaan Tenaga Kerja Tanam Bibit Padi. Jurnal Sosial Ekonomi Pertanian dan Agribisnis (inpress).

Swastika, D KS, Sumaryanto. 2012. Rantai Pasok Beras di Indonesia (Kasus Provinsi Jabar, Kalbar, dan Kalsel). Bogor: Bunga Rampai Rantai Pasok Komoditas Pertanian Indonesia, Pusat Penelitian Sosial Ekonomi dan Kebijakan Pertanian IPB.

Tommy P, Didik A, Kiki S. 2008. Inovasi teknologi mesin panen mini combine harvester mendukung penanganan panen dan pascapanen padi di Kalimantan Barat. Jurnal Enjineering Pertanian 6(1): 1382-1386.

Wahyuni D. 2016. Analisis Sistem Pengupahan "Bawon" pada Pertanian Padi (Studi Kasus pada Petani di Desa Gambar Kecamatan Wonodadi Kabupaten Blitar). Jurnal Bisnis Manajemen dan Perbankan 2(2): 121-140.

Wayyum R, Ahmad S, Usman M. 2010. Effects of SCOR on management of SC. International Journal of Management \& Organizational Studies 2(1): 85-91 